\title{
Measuring ERP System Success: Success Indicators and Structural Equation Modelling Approach
}

\author{
Ovais Ahmed R $\mathbf{R}^{\mathrm{a}}$, Dr. D.K. Mahalik \\ ${ }^{a}$ Research scholar, Business Administration Department, Sambalpur University, Sambalpur Odisha. \\ ${ }^{\mathrm{b}}$ Associate Professor, Business Administration Department, Sambalpur University, Sambalpur, Odisha \\ Email-id: aovais.ahmd@gmail.com, Email-id:bdkmahalik@suniv.ac.in
}

Article History: Received: 10 November 2020; Revised 12 January 2021 Accepted: 27 January 2021; Published online: 5 April 2021

\begin{abstract}
The study aims to analyse the system success of ERP Systems functioning at a leading Coal Producer Company in Odisha. The study is divided into two parts in the first part universal success indicators from the literature of ERP success measurement will be tested using factor analysis. In the second part of the study how factors influencing the success of ERP systems will be analysed using the updated G.Gable model by Princely Ifinedo. Data will be collected regarding 27 success indicators through a structured questionnaire from the end-users of ERP systems working at a Leading Coal Producer Company in Odisha. The sample size will be 330 i.e., at Confidence Level of 95(Ninety-Five)\% and Confidence Interval of 5 (Five) $\%$ for a total end-user population of 3300. A hypothesis is formulated and data analysis will be conducted by SPSS for Factor analysis and AMOS for SEM. The result obtain will show that whether success indicators are present or absent in the ERP Systems working at Leading Coal Producer Company in Odisha. Based on the presence or absence of success indicators through the data received from the end-users we can clearly say that whether ERP Systems implemented has served its purpose fully or partially
\end{abstract}

Keywords: ERP, End-user, Success Indicators, Hypothesis, CFA, Survey, Coal, SPSS, SEM, AMOS, Odisha.

\section{Introduction}

An ERP system can be referred to complex enterprise-level information systems the level of complexity is always based on the need for business processes synchronisation and integration of different applications functioning in the organisation which in-turn can smoothly automate the movement of material, flow of information, mobilisation of financial resources and have clear access to other operational activities taking place within an organization all these activities if done using a single database stored at a single location without having any physical constraints in accessing it then it can be called an ERP system (Kumar, Maheshwari\& Kumar, 2002).

The ERP software is an application that serves al the needs of an organisation from a single source of the database by having multiple benefits for the organisation, for example, Integration of data, improved efficiency of controlling the systems, reducing of costs, better and efficient inventory management control, monitoring of operations in real-time, all stakeholders information integrated into a single source (employees, suppliers, buyers, other monitoring agencies, government etc:,) it can also integrate a companies operations irrespective of its boundaries functioning in globally, improvement in primitive working processes, less paperwork office environments and many more uses to mention a few.

Defining successful performance of Enterprise solutions May vary depending on the stakeholders involved, since the project manager's point of view is different from the programmer's, senior manager's or client's, focusing on various factors such as budget, time, expense, efficiency, results, trust and protection of organisational database. Successful Performance of ERP systems from the user's point of view is to gain their satisfaction and increase their productivity at work. Benefits for the enterprise of implementing ERP systems from their point of vision can be the direct contribution to cash liquidity in an organisation or it can be acquiring a competitive edge over their rival firms, or it can be in terms of disruptive technologies in the markets they operate.

Over the past several decades, many companies whether it may be big or small in size throughout the world have invested a significant amount of resources such as time, money and energies in implementing and adapting Enterprise resource planning (ERP) systems.

However, despite these kinds of energies and useful resources being invested in ERP projects, a significant number of ERP projects have not achieved their desired organisation goals for which they were implemented in 
the first place which in turn caused financial instabilities for most corporations (Saade\&Nijher, 2016; CalisiretCalisir, 2004).

The past literature and research studies have shown that a majority of ERP implementation projects in larger organisations fail by around $40 \%$ and it is also found from the research studies that almost all the implementations i.e., by $90 \%$ are either exceeding their assigned deadlines or has over shooted the estimated financial budget by $67 \%$. Which has made to believe that the noble initiative of implementing an enterprise application to be deemed utterly not acceptable or infringeable (Chang \& Gable, 2000; Plant \&Willcocks, 2007).

As per the review of Esteves and Bohorquez (2007), the authors have found a piece of most critical information from their studies that only $47 \%$ of organisations who have implemented ERP applications have an efficient reviewing system placed in their organisation who reviews the progress of implementation of ERP systems during implementation and it was also found by the researcher that the post-implementation assessment of ERP systems is at a minuscule level only $15 \%$ of the organisation focuses or have a concern in evaluating their implemented ERP systems (Hsu et al., 2015). This latter viewpoint would warrant more attention, as the underperformance of ERP systems can result from the user's underuse of the program.

When we go through the literature on ERP systems studies and their functioning it appears that there are numerous studies have been done with a greater focus on a majority of the issues relating to either their adoption in an organisation or how it can be successfully implemented in an enterprise rather than any studies or fewer of them that can evaluate the functioning of ERP systems in their post-implementation stages. (Hsu et al., 2015)

\section{Literature Review}

The ERP project does not operate a business program out of a package because it requires a very dynamic development process (Pabedinskaite, 2010). It has its implementation methodology and follow-ups. Everything calls for time and other valuable resources at all stages i.e., before, during and after phases of implementation.

DarshanaSedera and Guy Gable in their study "A Factor and Structural Equation Analysis of the Enterprise Systems Success Measurement Model (2004)" A model with four measuring factors i.e., 1System Quality, 2Information Quality, 3Organisational Impact \& 4Individual Impact for first-order success explains the ESS phenomenon in the best way than any other models tested in the research studies.

Princely Ifinedo, in his research Enterprise Systems Performance Measurement Model: A Preliminary Study (2006) Due to their complex existence, it is difficult to assess ERP's success in implementing organisations. Besides, such systems can generate a wide range of benefits (tangible and intangible) for different users of the organization. Therefore, due to a lack of knowledge regarding this practice, some implementing organizations appear to have given up hope of evaluating the benefits or performance of their ERP.

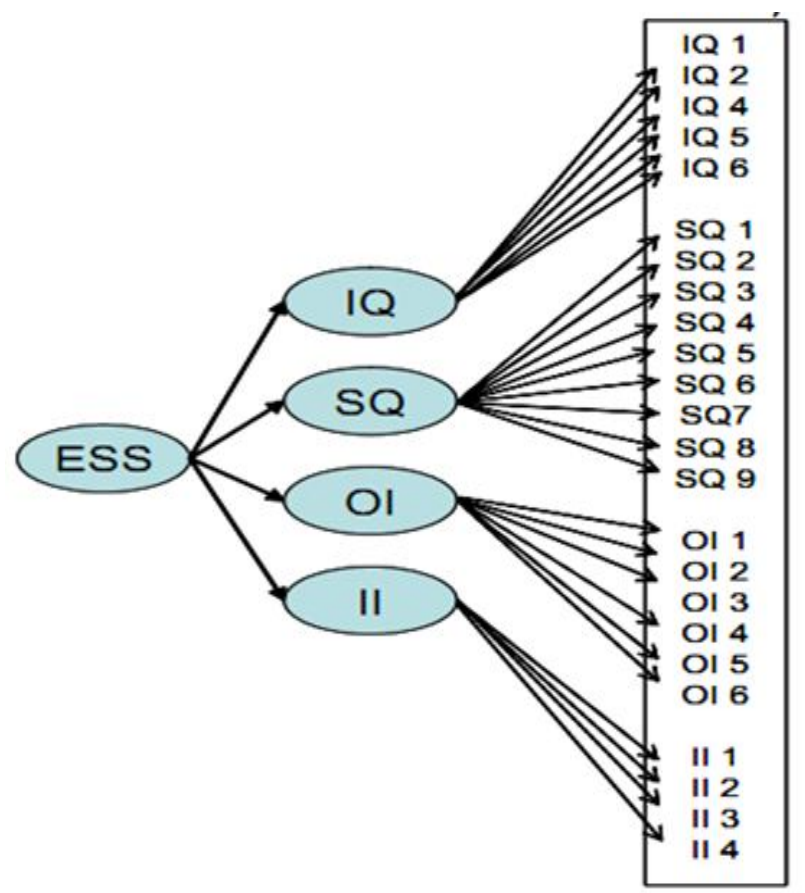

Fig-1: Enterprise System Success correlated model (Guy Gable et al., 2004) 
Kumar and Seddon et al. studies found and discussed the poor state of IS evaluation systems functioning within an organisation that has implemented and using it. concluded that "many businesses are not performing rigorous evaluations of all their IT projects and huge investments made on these adopted IT developments, it can majorly me due to a lack of in-house expertise in these system evaluation fields.

Hua-Yang Lin, Ping-Yu Hsu and Ping-Ho Ting (2006) It was also found the more the use of systems by its end users more will be user satisfaction. The use and user satisfaction had a directly proportional relationship.

Chun-Chin Wei in his research paper "Evaluating the performance of an ERP system based on knowledge of the ERP implementation objectives (2008)" The authors have found that there are several companies in the world who have dedicated their resources tremendously in selecting the best possible Enterprise systems for their organisations and have implemented them, but what they have not done is they have not long term neglected the need for assessing the efficiency of ERP systems which they have implemented and using it.

Princely Ifinedo (2007) It is important to note that ERP systems are different from other IT systems because ERP implementation includes technological, operational, managerial, strategic and organizational components.

ShahinDezdar and SulaimanAinin (2011) organisations are spending a huge some of there very crucial and important liquidator assets on implementations of ERP systems. It was found that the organisations have spent in a range of $1.5 \%$ to $6 \%$ of their total volume of annual sales on a single Enterprise solution which is a very huge expenditure (Mabert et al., 2001), and there are Enterprise solutions who has overshot over 90 per cent of estimated budgets. A.Selmeci, et al., (2012) We should have indicators by analysing which we can say that the performance is positive or negative.

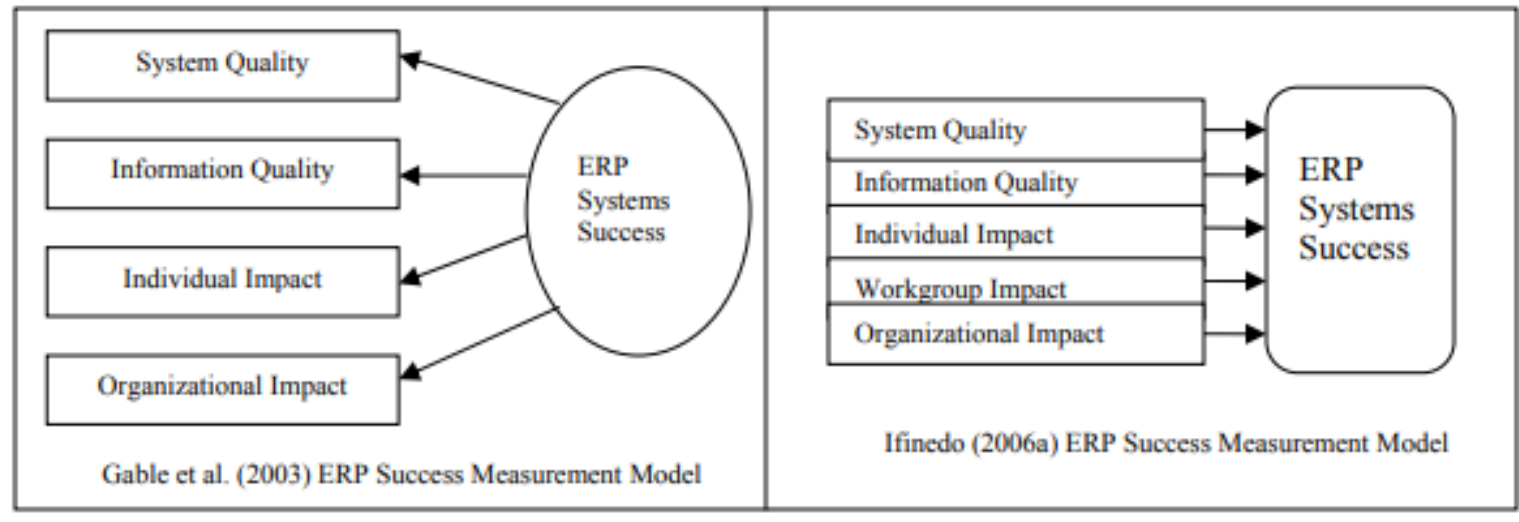

Fig 2 \& 3: Guy Gable et al., 2003 and Updated Princely Ifinedo Model of Enterprise Systems Success Measurement.

Joao Alexandre et al., (2012) The gains for the enterprise are real and expressed in the daily work through changes in knowledge management and the quality of their jobs, in the view of users. User satisfaction was the factor that most contributes to the success and effect on net benefits i.e., organizational level and individual level.

Asmamaw A. Mengistie (2013)An ERP deployment project can be deemed effective if it is on time, on budget and fulfils its goal. Organizations can minimize the risk of failures by consciously considering the Deployment Factors and necessary support and resources needed at every stage of ERP implementation phases.

Hongyi Sun et al (2015).,The implementation and smooth functioning of an enterprise system can be made a live example if the organisation follow a complex lifecycle view of the ERP systems, a step - by - step approach to the evaluation of their benefits they have impacted to the organisations both tangible and intangible in nature.

Suraj Kumar Mukti et al., (2014)Most of the ERP implementation projects witnessed failure at the end because factors that are vital to success both before and during the different implementation phases were not properly considered. The performance factors affecting ERP System Performance include Organizational Variables, Process Factors, Technology Factors, Information Factors, People Factors and Vendors / Consultant Factors, due to the lack of proper consideration of factors that are vital to success both before and during various implementation phases.

SiriluckRotchanakitumnuai (2017) Instead of a financial perspective, the IS scorecard evaluates business value. The reason for this is that the information system is a provider that provides service to the users in an organization it is not an explicit unit that generates revenue on its own. 
HaithamHmoudAlshibly (2015) IS performance evaluation and its success measurement is a multidimensional concept that can be measured at different levels, and the calculation of IS success was neither completely clear nor precisely defined.

SaraswatiJituri et al., (2018) Small and medium-sized enterprises (SMEs) face problems with the implementation of ERP systems, as there is a lack of knowledge, expertise and guidelines in this area.

Sonia Mekadmil et al., (2018) The decision to implement ERP systems in an organisation impacts every aspect of a business enterprise, any unsuccessful launch or implementations not serving their well-defined objectives for which they were implemented in the first place could damage the ability of an organisation to serve its customers who are the most important part of any enterprise to stay afloat in this competitive world.

M. NasiruYakubu et al., (2018) System Quality, Information Quality influenced behavioural intentions to use the ERP systems, service quality was found to significantly influencing user satisfaction and user satisfaction was found to influence the actual usage of ERP systems but was non-significant in its relationship with behavioural intentions.

\section{Research Methodology}

In the present research under focus we are adopting the model proposed and updated by Princely Ifinedo (2006a) in their research works of ERP success measurement. The model was updated from the previous model of ERP Success Measurement of Guy Gable et al., (2003). We are using all the five related dimensions for measuring the ERP success measurement of the ERP systems that are functioning in a Leading Coal Producer Company in Odisha. Due to confidentiality reasons, we are not nominating the name of the company in our research works and we are also not naming the particular type of ERP systems that are being functioned in the present company under focus. We will be using the name " a Leading Coal Producer Company in Odisha" to have a picture of the nature of business they are into and the type of challenges they are dealing with the ERP systems that are presently functioning within them.

\section{Objectives of The Study:}

- To know which factor has the most influence on making ERP systems successful and which factor is having the least impact in making it unsuccessful.

- To know to what extent ERP Systems has mapped the existing business process.

- To know the extent to which ERP systems are successful.

The Success Indicators collected from the previous studies are considered in this study for obtaining crucial data about the impact of ERP systems within the organisational boundaries. The success Indicators are mentioned below for measuring the success of ERP systems:

Table-1

\begin{tabular}{|l|l|}
\hline \multicolumn{2}{|l|}{ Success Indicators } \\
\hline System Quality \\
\hline 1 & To what extent the ERP System is Easy to use.? \\
\hline 2 & $\begin{array}{l}\text { To what extent the Functions Provided in the ERP System are easy to understand in performing your } \\
\text { work? }\end{array}$ \\
\hline 3 & To what extent the ERP System responds faster in performing your assigned tasks.? \\
\hline 4 & To what extent Connectivity is always available for your work.? \\
\hline 5 & $\begin{array}{l}\text { To what extent do you think the ERP Systems has Mapped your Existing Business Processes } \\
\text { pertaining to your department into a software entity.? }\end{array}$ \\
\hline Information Quality: \\
\hline 6 & $\begin{array}{l}\text { To what extent the Reports/Information provided by ERP systems are in the same formats as desired } \\
\text { by higher officials.? }\end{array}$ \\
\hline 7 & To what extent the Information provided by ERP System is accurate pertaining to your department.? \\
\hline 8 & To what extent the information provided by the ERP System is reliable in making decisions.? \\
\hline 9 & To what extent the information provided by ERP Systems is fully secured.? \\
\hline 10 & To what extent the Information/Reports can be accessed at any time using ERP Systems.? \\
\hline Service Quality: \\
\hline 11 & To what extent the Technical team has the expertise to easily understand and solve your issues.? \\
\hline 12 & $\begin{array}{l}\text { To what extent the Support available given by the ERP System technical team is prompt/accurate in } \\
\text { nature.? }\end{array}$ \\
\hline Individual Impact of ERP Systems: \\
\hline
\end{tabular}




\begin{tabular}{|l|l|}
\hline 13 & To what extent the ERP Systems Enhances your Creativity.? \\
\hline 14 & To what extent the ERP Systems Saves time for your tasks/duties \\
\hline 15 & To what extent the ERP Systems Improved your productivity \\
\hline Work Group Impact of ERP Systems: \\
\hline 16 & To what extent the ERP Systems Improves your organizational-wide communication? \\
\hline 17 & To what extent the ERP Systems helps to improve workers' participation in day to day activities? \\
\hline 18 & To what extent the ERP System improves the efficiency of sub-units? \\
\hline Organizational impact of ERP Systems: \\
\hline 19 & To what extent the ERP System provides you with a better competitive advantage.? \\
\hline 20 & $\begin{array}{l}\text { To what extent the ERP System has facilitated business process change/Business Process Re- } \\
\text { engineering in the Organisation.? }\end{array}$ \\
\hline 21 & To what extent the ERP System Allows you for better use of organizational data resource.? \\
\hline 22 & To what extent the ERP System has helped in the reduction of Manpower requirement.? \\
\hline 23 & To what extent the ERP System has helped in Cost reduction.? \\
\hline Net Benefits of ERP Systems: \\
\hline 24 & To what extent the ERP Systems improves your performance while performing your assigned duties.? \\
\hline 25 & $\begin{array}{l}\text { To what extent the ERP Systems have streamlined the Business Process with the best of Industry } \\
\text { Standards.? }\end{array}$ \\
\hline 26 & To what extent the ERP Systems Improves the overall productivity of the organisation.? \\
\hline 27 & $\begin{array}{l}\text { To what extent the implementation of ERP Systems has an Overall positive Impact on your } \\
\text { organisation.? }\end{array}$ \\
\hline
\end{tabular}

\section{Data Collection Instruments and Techniques:}

Both primary and secondary data is used during the study. Secondary data is accessed from different sources including textbooks, journals, and company documents as well as online resources. Primary data, on the other hand, is directly collected through questionnaires and interviews.

\section{Scope of the Study:}

The project has a clear focus on ERP Systems presently functioning at Leading Coal Producer Company, whose mines spread throughout Odisha and about 2700sq km to analyze its impact on the end-users.

\section{The hypothesis of the study:}

H1: There is a significant effect of Information quality on Enterprise System Success.

H2: There is a significant effect of System quality on Enterprise System Success

H3: There is a significant effect of Individual impact on Enterprise System Success.

H4: There is a significant effect of Workgroup impact on Enterprise System Success.

H5: There is a significant effect of Organisation impact on Enterprise System Success.

H6: All factors equally contribute to the Enterprise System Success.

\section{The population of the Study:}

1.Financial Information System (150), 2. File Tracking System (75), 3.Materials Management System (45) 4.Personnel Information System (25), 5.Sales and Marketing (16), 6.Production Management System (08), 7.Payroll (04), 8.General (03), 9.Equipment Management System (03), 10.Management Information System (01) $=$ Total 330 .

\section{Data Analysis and Presentation:}

Data analysis will be conducted by SPSS and AMOS for SEM. The result obtain will show that whether success indicators are present or absent in the ERP Systems working at Leading Coal Producer Company. Interpretative Structural Modelling/Structural Equational Modelling- To analyse how one factor is influencing the other factors.Regarding the reliability of the measures, the Cronbach Alpha is 0.83 , which is much above the 0.70 limits as recommended by Nunnally, it indicates that the research measures are of high reliability in accessing the objective of the study. 
Table-2

\begin{tabular}{|l|l|l|}
\hline SI no & Module & End-Users \\
\hline 1 & Financial Module & 150 \\
\hline 2 & File Tracking Module & 75 \\
\hline 3 & Materials Management Module & 45 \\
\hline 4 & Personal Information Module & 25 \\
\hline 5 & Sales and Marketing Module & 16 \\
\hline 6 & Production Management Module & 08 \\
\hline 7 & Payroll Module & 04 \\
\hline 8 & General Module & 03 \\
\hline 9 & Equipment Management Module & 03 \\
\hline 10 & Management Information Module & 01 \\
\hline \multicolumn{2}{|r}{ Total Population of End Users } & 330 \\
\hline
\end{tabular}

Table 3: Case Processing Summary

\begin{tabular}{|l|l|l|l|}
\hline \multicolumn{2}{|c|}{} & $\mathrm{N}$ & $\%$ \\
\hline \multirow{4}{*}{ Cases } & Valid & 330 & 100 \\
\cline { 2 - 4 } & $\begin{array}{l}\text { Exclude } \\
\mathrm{d}\end{array}$ & 0 & 0 \\
\cline { 2 - 4 } & & & \\
\cline { 2 - 4 } & Total & 330 & 100 \\
\hline
\end{tabular}

Table 4: Reliability Statistics

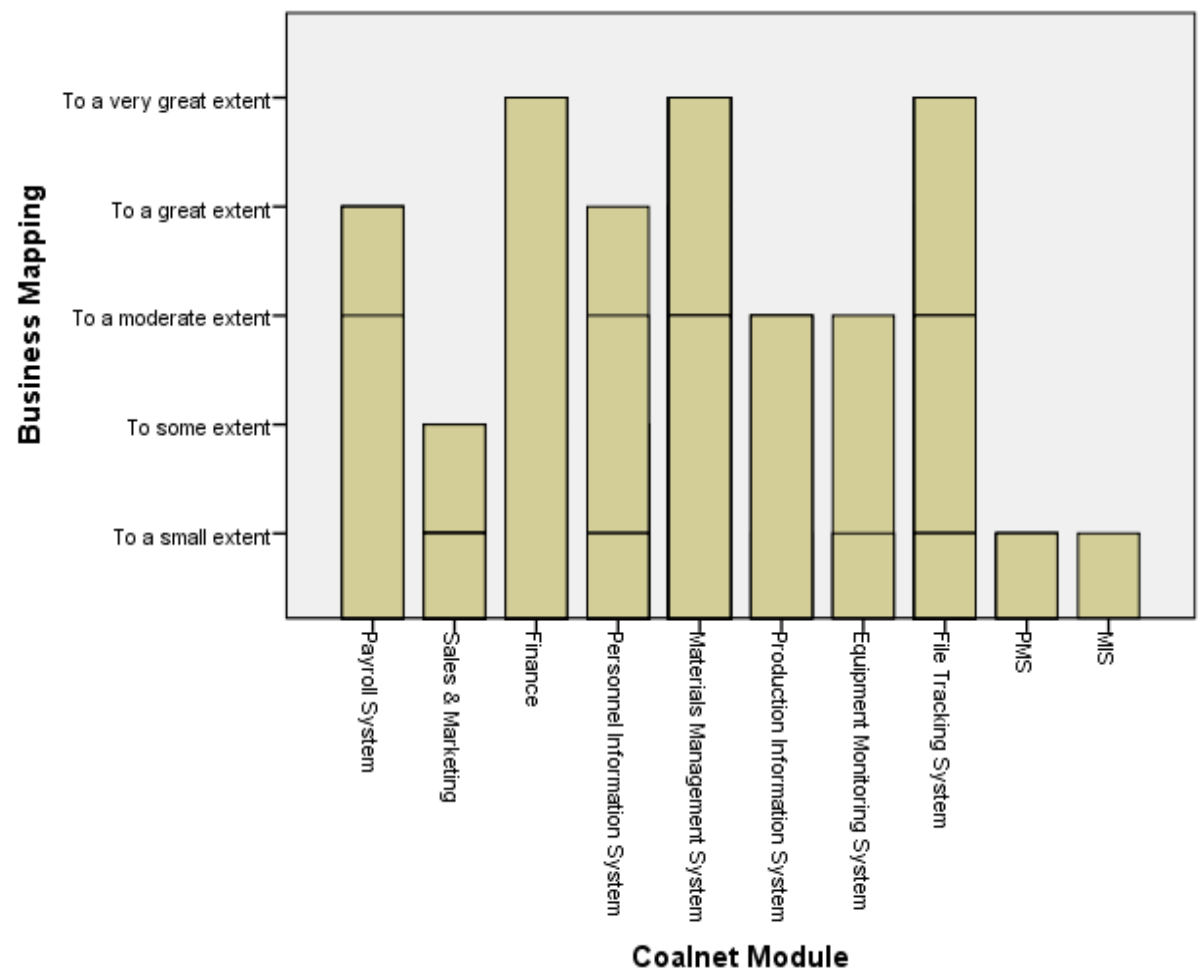

Figure-4: Different Module and their present Business Process Mapping in ERP Software.

The results obtained from analysing the responses of the end-users using the ERP systems particularly to the level of computerisation done into their workflow process i.e., Business Process mapping of all the physical functional departments is done into a Software Entity of ERP Systems. It has been found that the departments such as Finance, Materials Management and File Tracking Systems are mapped to a very greater extent into a software entity, departments such as Payroll and Personnel Information System are mapped to a great extent, department such as Production Information System and Equipment Monitoring System are mapped to a moderate 
extent, department such as Sales \& Marketing is mapped to some extent, and department such as PMS and MIS are mapped to a small extent in ERP systems.

\section{Information Quality and Enterprise system success:}

Information quality mainly refers to the information obtained from the Enterprise systems that can be made use from the user's point of view in completing his assigned task and helps him in making accurate and valuable decisions keeping in mind the organisation goals to be achieved. The information sought from the system can be of different types it might be the particulars of the employees working in a particular discipline, it might be about his nature of work and job profile, it can be about the availability/non-availability of materials in the stores, it might be about the last purchase details of the materials in need, about the previous consumption pattern of the materials, it can be about the total expenditure in a particular head of accounts in a given financial year and time, it might be about the production of goods and their dispatches per day, biweekly, monthly or annually, it might be about the various types of equipment functioning and further requirement of any in achieving assigned production targets. There is no doubt in mentioning that whether an organisation big or small public or private in nature they all require quality of information is able to function more efficiently and in tandem to achieve the desired organisational goals with optimum utilisation of their resources. It is also evident from the previous studies of ERP success measurement that the greater the quality of Information obtained from an Enterprise system greater will be the satisfied user and which in turn helps in making the ERP systems a success.

\section{System Quality and Enterprise System Success:}

System quality may be usually defined as the quality of content a system can produce while engulfing data from the legacy systems. usually end-users directly compare the present system in hand with the previous legacy systems working in an organisation. Any company in the world will think of implementing enterprise solutions to only improve their quality of work and handling of organisational data most effectively and efficiently so that they can pierce their intense business competition. System quality is overall considered as to how the enterprise systems function within the organisation considering the overall outlook of the system from a users perspective it might be the ease in using the systems, it might be the ease in understanding the systems for their assigned task, it might be for the prompt response from the system while interacting with it and it can also be the uninterrupted availability of the systems in performing their assigned tasks. With references found in numerous ERP success literature, there is no doubt in saying that the success of Enterprise systems is directly proportional to the system quality. Higher the quality of the system greater will the satisfied users and in turn, will be the contribution to ERP success within an organisation.

\section{Service Quality and Enterprise System Success:}

Service quality usually refers to the quality of service provided by the first party or the third-party vendor in managing and smooth running of Enterprise systems. In our case of study, the services of ERP systems are managed internally by the System department of the company by hiring a skilled service team who has experience in maintaining databases. The whole responsibility of making and running the system smoothly lies with the System. The system department has hired the skilled employees of TCS who in-turn look after the complex works involved in managing and analysing databases. But the ultimate decision making and how the systems to function are held by the System department of the Company itself. Thereby we are not treating the service quality of the Enterprise system as a separate factor, the variables representing the service quality criteria such as possessing the expertise to easily understand and solve the user issues and availability of support is in prompt and accurate is being included in System quality itself. For having a better analysis of the ERP success measurement.

\section{Individual Impact and Enterprise System Success:}

Individual Impact is nothing but the effect that the Enterprise systems have on the functioning of jobs performed by the individual which are assigned to them. The individual impact is compared in terms of jobs performed by the users before the implementation of Enterprise systems and jobs performed after Implementation of Enterprise systems within an organisation. It is not necessary that the users to have a positive view about the Enterprise systems once they are implemented in the early stages, the literature says that the users have a learning curve of six months to interact with the systems and get accustomed to its uses and benefits as the experience with using the systems increases so as their mastery in using and understanding the systems. The impact that the enterprise systems have on the individual user level on performing their day to day routine activities can be such as to help the users complete their task quickly and accurately by saving enough time for other tasks, it might be on developing the thinking of the end-users on a very broad level as they can have access to all the data of the organisation as a whole within their reach, it can also be on developing the creativity of individual users in performing their jobs with more innovative and productive and which in turn can benefit the organisations in a long run. When the Enterprise system has a positive impact on the Individual level we can say that the ERP systems implemented in an Organisation are a Success. 


\section{Work Group Impact and Enterprise System Success:}

A workgroup in an organisation is nothing but a group of people working together to achieve a specific job or task assigned to the group. The group task and goals are always in accordance with the organisational goals of an enterprise. Appreciating and recognizing that the working group is meant to be a platform for collaboration and engagement is important for the members. Participants embody members' preferences and opinions from diverse cultural groups who happen to have a shared interest in the outcomes of the WG. Maintaining and reinforcing contact lines between all interested parties is also important to the effective functioning of the groups. The Impact on Workgroup is a collective impact on all the individuals working in those groups. Workgroups are usually formed in large organisations as the organisation under consideration in our research study is one of the largest coal-producing company in the Country. The individuals working under these groups should always feel the robustness of the information system otherwise there will be a lack of coordination and cooperation between the individual working together as they are supposed to work in tandem and in real-time. The collective impact that the enterprise systems are supposed to have on the Workgroups should be in a positive sense or else the users within the group will get demotivated and in turn will not be able to achieve either the assigned group tasks or organisational goals in a real sense. The impact on workgroups can be in terms of effective and streamless communication well within the group and throughout the organisation also. It can also be in terms of improving the participation of the workers in effectively performing their assigned duties. Last but not least it can be in terms of improving the efficiencies of sub-units functioning within the boundaries of the Organisation. Once the workgroup has a positive impact regarding the enterprise systems functioning it can contribute majorly in making the Enterprise systems a success.

\section{Organisational Impact and Enterprise System Success:}

Organisational Impact majorly measures the impact that the Enterprise systems have on the functioning of the organisation as a whole. The Organisation always implements Enterprise systems to have a positive and effective transition in day to day functioning of their business requirements. The management of the organisation will have a clear goal in their minds before implementing systems and what is results to be obtained from these systems. But down the line, it is a lengthy and complex process to successfully implement ERP systems within an organisation. The bigger the organisations in size and geographical locations remotely spread more complex will be the smooth functioning of these systems. As the focused organisation under research is Leading Coal Producer Company, a Coal Mining Company which has widespread locations throughout Odisha and its mines are spread around 2700sq $\mathrm{km}$ in remote areas where there are no or limited network connectivities in mining areas.

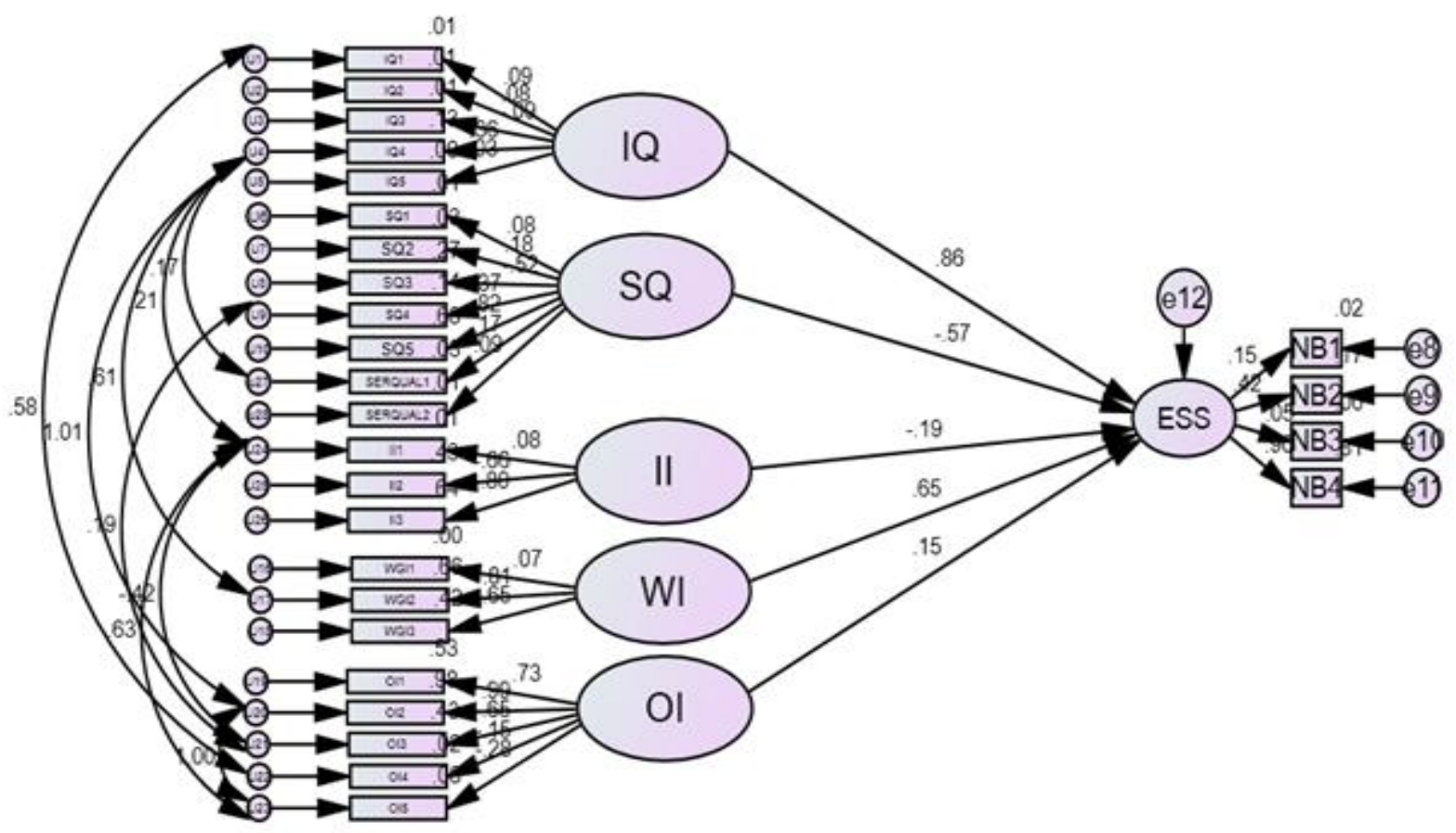

Fig-5 ERP Success Measurement Model 
The success of enterprise systems can only be analysed once they are thoroughly implemented and have started functioning in an organisation and have at least completed more than six months to one year from their shakedown phase. As in our case of study the Colanet ERP systems have completed a period of more than 7years from the date it was made functional and made reactivated in the organisation in the year Jan 2013. Following this line of reasoning, Ifinedo et al. (2010) proposed an ERP In the post-implementation process, the program is deemed successful because it improves future gains by cut shorting organisational expenditures, satisfaction with the end-users, increasing operating efficiency, and so on. Thereby the variable we used to test organisational impact is whether the Enterprise systems provide a better competitive advantage for the Organisation, to what extent the Enterprise systems have managed to have a better Business process re-engineering done keeping in mind the best standards implemented across the globe. In what best way the organisational data as a whole is put to use for making effective decision making and better control of the organisational resources. To what extent the Enterprise systems have played a role in effectively reducing the manpower requirements to perform certain prescribed jobs which were previously laborious in legacy systems and last, not the least how the systems have made the economies look better whether it might be in the reduction of costs and whether it can be returned on investment of resources being invested in the implementation of enterprise systems.

It is also clear from most of the previous literature studies that the impact of positive on the organisation as a whole will certainly make the ERP systems successful. The Organisational Impact as a whole will be a major contributor in deciding whether the systems can be called a success or not.

From the values obtained through the Structural Equational Modelling approach of the ERP success measurement model as developed in figure 5, it is evident that the factors that are contributing to the success of ERP implemented in MahanadaiCoalfielsds limited are Information quality of the ERP systems which has a positive regressional value of 0.86 , followed by the contribution of Workgroup impact with a value of 0.65 that the ERP systems have influenced on each of the individuals working in such groups functioning in a larger organisation to achieve common specific assigned group goals and the positive contribution is also from the factor Organisational impact with a value of 0.15 which states that the ERP systems has contributed to an extent on the well being and has generated positive results in favour of organisation as a whole.

Testing of Hypothesis:

\begin{tabular}{|l|l|c|c|}
\hline & Hypothesis & Values & Accepted/Rejected \\
\hline H1 & $\begin{array}{l}\text { There is a significant impact of Information quality on } \\
\text { Enterprise System Success. }\end{array}$ & 0.86 & H1 Accepted \\
\hline H2 & $\begin{array}{l}\text { There is a significant impact of System quality on } \\
\text { Enterprise System Success }\end{array}$ & -0.57 & H2 Rejected \\
\hline H3 & $\begin{array}{l}\text { There is a significant impact of Individual impact on } \\
\text { Enterprise System Success. }\end{array}$ & -0.19 & H4 Accepted \\
\hline H4 & $\begin{array}{l}\text { There is a significant impact of Workgroup impact on } \\
\text { Enterprise System Success. }\end{array}$ & 0.65 & H5 Accepted \\
\hline H5 & $\begin{array}{l}\text { There is a significant impact of Organisation impact on } \\
\text { Enterprise System Success. }\end{array}$ & $\begin{array}{l}\text { He.15 Rejected } \\
\text { Success. }\end{array}$ \\
\hline H6 & $\begin{array}{l}\text { All factors equally contribute to the Enterprise System } \\
\text { differently. }\end{array}$ & Hactors contribute \\
\hline
\end{tabular}

The factors that have not contributed to making the ERP systems a successful one are Systems quality, users believed that the quality of ERP systems was not up to the mark when they look around with ERP systems functioning in the present world. As per the user experience, the systems have not at all mapped all the departments functioning within the organisation into a software entity, which means 3 departments were mapped to a great extent in ERP systems such as Finance Management Module, Materials Management Module and File tracking Systems (Dispatch Department). In all the other remaining departments the work was done through previous practices i.e., some part was done through and most of the part was through manual computing. As all the systems were not in the purview of a single database platform i.e., ERP systems thereby it controverse the Nobel cause of any functional ERP systems. As the database of such ERP systems is not complete and they cant guide the Managers or Top management of the company is taking any single decision with the reports solely generated from these half baked systems.

Another factor that doesn't contribute to making the ERP systems success is Individual Impact, the users in the organisation using these systems felt that the ERP systems don't contribute much to the benefits of an Individual user as a single entity either in increasing his creativity or in increasing his productivity. The users felt that they are using a system that is similar to the legacy systems with no much impact on their working styles and improvements. They also felt that only limited options in their module were functional and most of the options provided in the modules were not functional. There were no much data available to substantiate the claim that the 
ERP systems have reduced their working time in completing jobs assigned to them. This means the ERP systems had a small extent impact on individual users.

\section{References}

Alexandre, J.; and Isaias, P. Information Systems Success: Measuring Wiki Implementation Success, Based on the DeLone\& McLean model. LNBIP 129, pp. 212-224, 2012.

Alshibly, H, H. Investigating Decision Support System (DSS) Success: A Partial Least Squares Structural Equation Modeling Approach. Journal of Business Studies Quarterly, Volume 6, Number 4, 2015.

Chang, S. \& Gable G. (2000). A comparative analysis of major ERP life cycle implementation, management and support issues in Queensland government", Queensland University of Technology, Information Systems Management Research Center, 1152-1166.

Calisir, F. \&Calisir, F., 2004.The relation of interface usability characteristics, perceived usefulness, and perceived ease of use to end-user satisfaction with enterprise resource planning (ERP) systems.Computers in human behavior, 20(4), 505-515.

Dezdar, S.; Ainin, S. Measures of success in projects implementing enterprise resource planning.International Journal of Business Performance Management, Vol. 12, No. 4, 2011.

Esteves, J., \&Bohorquez, V. (2007).An Updated ERP Systems Annotated Bibliography: 2001-2005. Communications of the Association for Information Systems, 19, pp-pp.

Gable, G.; Sedera, D.; and Chan, T. Enterprise systems success: A measurement model. ICIS Proceedings. 48 (2003).

Hsu, P, F.; Yen, H, J, R. \& Chung, J.C., 2015. Assessing ERP post-implementation success at the individual level: Revisiting the role of service quality. Information \& Management, 52, pp. 925-942.

Ifinedo, P., Rapp, B., Ifinedo, A. \&Sundberg, K., 2010. Relationships among ERP post-implementation success constructs: an analysis at the organizational level, Computers in Human Behavior, 26(5), pp. 1136-1148.

Ifinedo, P. Enterprise systems success measurement model: A preliminary study", Journal of Information Technology Management Volume XVII, Number 1, p.14-33, 2006.

Ifinedo, P. Investigating the relationships among ERP systems success dimensions: A Structural Equation Model. Issues in Information Systems Volume VIII, No. 2, 2007.

Jituri, S.; Fleck, B.; and Ahmad, R.A Methodology to Satisfy Key Performance Indicators for Successful ERP Implementation in Small and Medium Enterprises. International Journal of Innovation, Management and Technology, Vol. 9, No. 2, April 2018.

Kumar, V., Maheshwari, B., \& Kumar, U. (2002). Enterprise resource planning systems adoption process: A survey of Canadian organizations. International Journal of Production Research, 40, 509-523.

Lin, H, Y.; Hsu, P, Y.; and Ting, P, H. ERP Systems Success: An Integration of IS Success Model and Balanced Scorecard. Journal of Research and Practice in Information Technology, Vol. 38, No. 3, August 2006

Mabert, V.M., Soni, A. and Venkataramanan, M.A. (2001) 'Enterprise resource planning: common myths versus evolving reality', Business Horizons, Vol. 44, No. 3, pp.69-76.

Mengistie, A, A.; Heaton, D, P.; Rainforth, M. Analysis of the Critical Success Factors for ERP Systems Implementation in U.S. Federal Offices. ERP Future Conference Revised Papers Book, Innovation and Future of Enterprise Information Systems. P-183-198, 2013.

Mekadmi, S.; and Louati, R.An Evaluation Model of User Satisfaction with Enterprise Resource Planning Systems.The Electronic Journal Information Systems Evaluation, 21(2), pp. 143-157, 2018.

Mukti, S, K.; Tripathi, P.; and Rawani, A, M. Identification of Factors and Indicators for Success Measurement of ERP System.IPEDR.Volume 75, 24, 2014.

Pabedinskaitè, Arnoldina. "Factors of Successful Implementation of ERP Systems Problems of ERP implementation Success Factors in the Process of Implementation of ERP Systems.” 2010. 691-697.

Plant, R. \&Wilcocks, L. (2007). Critical success factors in international ERP implementations: A case research approach. Journal of Computer Information Systems, 47(3), Retrieved January 15, 2011.

Rotchanakitumnuai, S. Measuring ERP Implementation Success with a Balanced Scorecard. Twenty-third Americas Conference on Information Systems, Boston, 2017

Saade, R. \&Nijher, H., 2016. Critical success factors in enterprise resource planning implementation: a review of case studies. Journal of Enterprise Information Management, 29(1)

Sedera, D.; and Gable, G. A factor and structural equation analysis of the enterprise systems success measurement model. Twenty-Fifth International Conference on Information Systems, p.449-464, 2004.

Selmeci, A.; Orosz, I.; Gyorok, Gy.; and Orosz, T. Key Performance Indicators used in ERP performance measurement applications. IEEE 10th Jubilee International Symposium on Intelligent Systems and Informatics, September 20-22, 2012,

Seddon, P. B., Graeser, V., Willcocks, L. P., 2002. Measuring organizational IS effectiveness: An overview and update of senior management perspectives, The DATABASE for advances in IS, 33, 2, 11-28. 
Sun, H.; Ni, W.; and Lam, R. A step-by-step performance assessment and improvement method for ERP implementation: Action case studies in Chinese companies. Computers in Industry 68, 40-52, 2015.

Wei, C, C. Evaluating the performance of an ERP system based on the knowledge of ERP implementation objectives. International Journal of Advance Manufacturing Technology Volume 39:168-181, 2008.

Yakubu, M, N.; and Dasuki, S, I. Assessing Elearning Systems Success in Nigeria: An Application of the DeLone and McLean Information Systems Success Model. Journal of Information Technology Education: Research, 17, 182-202, 2018 